\title{
The bioactive contents and antioxidant activity of honey bee nest extract of Apis dorsata Binghami from the North Sulawesi
}

\author{
Mokosuli Yermia Semuel ${ }^{1,2^{*}}$, Eva Sherly Nonke Kaunang ${ }^{3}$, Jacklin Stella Manopo ${ }^{2}$ \\ 'Laboratory of Bioactivity and Molecular Biology, State University of Manado, Kampus Unima Tondano, \\ Minahasa, Sulawesi Utara, Indonesia \\ ${ }^{2}$ Departement of Biology, Faculty Mathematics and Natural Science, State University of Manado, Kampus \\ Unima Tondano, Minahasa, Sulawesi Utara, Indonesia. \\ ${ }^{3}$ Departement of Education Biology, Faculty Mathematics and Natural Science, State University of Manado, \\ Kampus Unima Tondano, Minahasa, Sulawesi Utara, Indonesia
}

*Corresponding author email: yermiamokosuli@unima.ac.id

Received March 8; 2019; Accepted May 20; 2019; Available online November 30, 2019

\begin{abstract}
Apis dorsata Binghami is a Sulawesi endemic honey bee. Apis dorsata Binghami cannot be bred, so it still lives wildly in the forests of Sulawesi. However, Apis dorsata Binghami produces more honey, compared to all honey bee species. Furthermore, the diversity of plants as a source of nectar, pollen and plant resin, which is used in the formation of nests and honey is more, than all types of honey bees in the world. Ethnomedically, the Minahasa community has long used honeynest for degenerative diseases such as hyperlipidemia and cancer. Nevertheless, there have been no research reports on bioactive content and bioactivity of Apis dorsata Binghami nest extract. This research was aimed to determine the bioactive content of honey bee nest and to obtain the inhibitory concentration 50 (IC 50 ) antioxidant activity of honey bee nest extract of Apis dorsata Binghami. Honey bee nest was obtained directly from the forest of Minahasa peninsula, North Sulawesi, Indonesia. Extraction of fresh honey bee nest was conducted using maceration method. Bioactive content analysis was carried out by the Harborne method, followed by analysis using UV Vis spectrophotometer and High performance liquid chromatography. $I_{50}$ antioxidant activity of honey bee nest extract was obtained using DPPH free radical reduction method. The results showed that Apis dorsata Binghami honey bee nest extract contained alkaloids, flavonoids, saponins, tannins, steroids and triterpenoids. Identified flavonoids displayed the highest phytochemical content. Based on the results of HPLC and UV Vis spectrophotometer analysis, there were 20 flavonoid derivatives found in honey bee nest samples in Minahasa. Ethanol extract and $n$-hexane extract showed high free radical reduction activity compared to vitamin $\mathrm{C}$ as a control treatment. However, ethanol extract produced the highest DPPH free radical reduction activity.
\end{abstract}

Keywords : Bioactive, Apis dorsata Binghami, nest extract, antioxidants

\section{INTRODUCTION}

Apis dorsata Binghami is an endemic bee of Sulawesi that still lives naturally in the forest and cannot yet be breed. Apis dorsata Binghami was discovered by Alfred Russel Wallace during an expedition to Sulawesi Island (Celebes) in the $18^{\text {th }}$ century (Hadisoesilo, 2001; Raffiudin, 2002; Mokosuli, 2013). Apis dorsata Binghami produces the most productive honey compared to other honeybee species (Otis, 1991; Hadisoesilo, 2001). This bee makes a nest with only one comb hanging from tree trunks and twigs, open ceilings, and rocky cliffs (Hadisoesilo, 2001; Raffiudin, 2002). In spite of these advantages, they are not commonly cultivated as Apis mellifera and Apis cerana honeybees. Until now, scientists have not succeeded in cultivating $A$. dorsata in a closed form, so that it still lives naturally in the forest (Otis 1991; Hadisoesilo 2001; Raffiudin, 2002). However, deforestation is rapidly decreasing their nesting in Minahasa, North Sulawesi, Indonesia (Mokosuli, 2013; Hadisoesilo et al. 2007; Sawaya et al. 2009), affecting their migration and survival. Therefore, information on the composition of Apis dorsata Binghami nest and propolis of this native honeybees, as well as the plants they visit as source of nectar, pollen, resins and other compounds from plants, is of primary importance.

Honey, bee venom and honey bee nest are honey bee products, which are prepared by worker bees. The composition and content of honey, venom and honey bee nest is very dependent on the diversity of plant sources of bee feed. Unlike Apis mellifera, where the diversity of food sources is limited, Apis dorsata Binghami has a very large variety of feed sources. The range of flying worker bees in search of feed plants is also further than Apis mellifera because of differences in body size (Mokosuli, 2013). Apis dorsata is known as a giant bee because it has the 
largest body size compared to other honey bee species on earth (Hadisoesilo 2001; Raffiudin, 2002). Previous research has been conducted, found that the venom content and Apis dorsata Binghami honey are strongly influenced by variations of flowering plants adjacent to their nests. Apis dorsata found in the Kombi of Minahasa Regency in the season of clove plants produces honey with the aroma of cloves (Mokosuli, 2013). In addition to honey and venom, honey bee nest is a potential bioactive source of medicine that has the potential to be studied.

The honey bee nest is the structure used by bees as a place to live and raise their offspring. The inside of the honey bee nest is a collection of hexagonal structures made of wax. Bees use this hexagonal space to store honey, bee pollen, eggs, larvae and bee pupae (Nazzi, 2016). The honey bee nest is a refuge for bee colonies from attacks by bacteria, fungi, viruses and predators, as well as a place to produce honey, bee pollen, and a place to grow bee eggs. The condition of the honey bee nest greatly affects the quality of honey and what is produced. Honey is generally free from pathogenic microbes (Perez, Suarez, Pena-Vera, onzalez \& Vit, 2013). The content of compounds in honey bee nest serves as a protective and determinant of the quality of honey including flavonoids which are natural phenol compounds and bees wax (Ra'ed, Ibrahim, Rula \& Mosa, 2008; Pasupuleti, Sammugam, Ramesh \& Gan, 2017).

Propolis is the largest component of honey bee nest constituent. Propolis is a sticky, gummy, resinous substance collected by honeybees from various plant sources (Coneac et al, 2008). Propolis is produced by bees from sap taken from parts of plants that produce sap, especially plant buds (Nazzi, 2016; Bankova, 2005). The sap is the basic ingredient for propolis. Sap is brought into the honey bee nest by worker bees and mixed with wax (a type of wax) and flower pollen. With the help of bee saliva, this mixture is processed to become flexible to form propolis (Suseno, 2009). Propolis contains aromatic compounds, flavonoids, quercetin, terpenoids, and sugar. In addition, there are also minerals $\mathrm{Fe}, \mathrm{Ca}$, $\mathrm{Mg}, \mathrm{K}, \mathrm{Na}$, and $\mathrm{Zn}$. Natural propolis contains a number of amino acids such as valine, isoleucine, leucine, proline, alanine, and glycine which play a role in the formation of body cells. Propolis is also rich in vitamin B1, vitamin B2, vitamin B3, and vitamin B6 (Choi, Shimomura, Kumazawa \& Ahn, 2013).

Bee propolis extract has antidiabetic activity, antiaterogenic, antimicrobial and antifungal mainly due to polyphenol content (Daleprane \& Abdalla, 2013; Barrientos et al. 2013; Saavedra et al. 2011; Veloz et al. 2016). The benefits of flavonoids in the human body function as antioxidants so it is very good for cancer prevention. The benefits of flavonoids include anti-inflammatory, preventing bone loss, and as an antibiotic (anti-bacterial and anti-virus) (Waji and Sugrani, 2009; Redha, 2010; Seal, 2016). The benefits of quercetin are believed to protect the body from several types of degenerative diseases by preventing the occurrence of fat peroxidation (Waii \& Sugrani, 2009). Quercetin shows the ability to prevent the oxidation process of LDL cholesterol by capturing free radicals and holding transition metal ions (Repi, R. A., Mokosuli, Y.S., Ngangi, J., \& Sumampouw, H. M. 2013). Polyphenol derivatives as antioxidants can stabilize free radicals by complementing the lack of electrons possessed by free radicals, and inhibiting the occurrence of chain reactions of free radical formation (Mokosuli, 2008). Polyphenols are components responsible for antioxidant activity in fruits and vegetables (Hattenschwiller and Vitousek 2000). Aside from being an antioxidant, polyphenols can also reduce cholesterol, LDL and triglyceride levels. The reduction mechanism is by increasing the activity of lipoprotein lipase, so that the catabolism of triglyceride-rich lipoproteins such as VLDL and IDL increases (Redha, 2010). HDL cholesterol levels increase indirectly due to decreased triglyceride levels of VLDL or due to increased production of apo Al and apo All (Inggrid \& Santoso, 2014). The effect of decreasing LDL cholesterol is thought to be related to increased clearance of VLDL and IDL in the liver so that LDL production decreases (Mokosuli, 2013). Ethnomedically, the Minahasa community has long used honeynest for degenerative diseases such as hyperlipidemia and cancer. Nevertheless, there have been no research reports on bioactive content and bioactivity of Apis dorsata Binghami nest extract.

\section{EXPERIMENTAL SECTION}

\section{Tools and Materials}

The tools used in this study include : UV-Vis Spectrophotometer Parkin Elmer, Nanophotometer Implan, Rotary Evaporator Heidolph, Automatic Qiaexel electrophoresis Qiagen, HPLC Shimizu, micropipette eppendorf, sample boxes, waterbaths, UV Cabinets, glassware etc. The materials used include: ethanol p.a. merck, Methanol p.a. Brand, Merck n-hexane, Merck ethyl acetate, Merck chloroform, Pareaksi Dragendorf, Pareaksi Mayer, Pareaksi Wagner, HCL, Diphenyl pikri hydrazill (DPPH) Merck, propylene glycol (Merck) $\mathrm{K}_{2} \mathrm{Cr}_{2} \mathrm{O}_{7} 1$ $\mathrm{N}, \mathrm{H}_{2} \mathrm{SO}_{4}$, acetonitrile, standard phenol (Merck), standard flavonoids (Merck), antihyperlipidemia analysis kits, bioactive analysis kits, HPLC columns etc. 


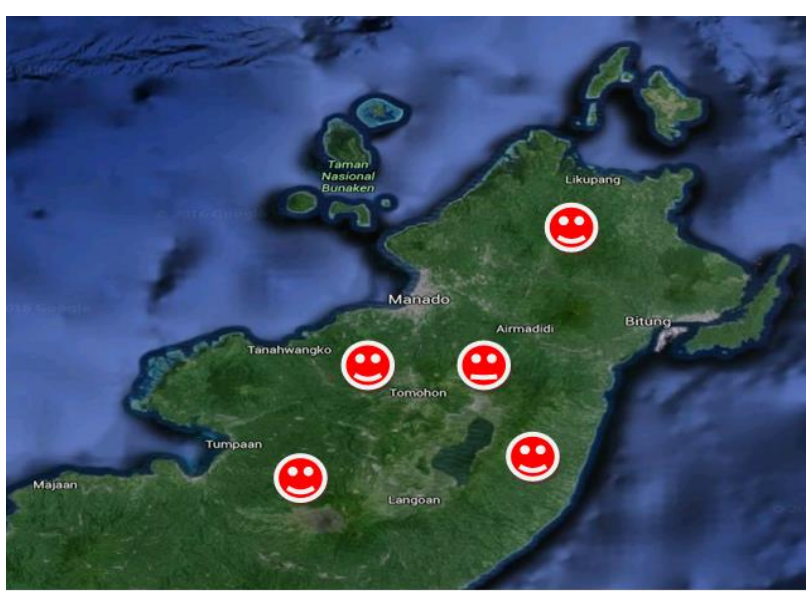

Figure 1. Location of a honey bee nest samples (red white circle). (Map source: google earth, www.google.com)

\section{Honey Bee Nest Samples}

Honey bee nest were obtained from the Minahasa peninsula, North Sulawesi province, Indonesia (Figure 1). Honey bee nest is taken at natural nesting sites in the forest, collected in a sample box with controlled temperature (temperature $25^{\circ} \mathrm{C}$ ). The sample was carried out to the Laboratory Bioactivity and Biomolecular Department of Biology, State University of Manado, for analysis.

\section{Extraction}

Extraction of Apis dorsata Binghami honey bee nest, carried out by maceration method. The fresh honey bee nest consists of a bag of honey, a pollen bag, an egg bag, and a nest cover. Whole honey bee nest, then blended until smooth. Comparison of honey bee nest solvents and simplicia 1: $4(\mathrm{~b} / \mathrm{v})$, (250 grams of honey bee nest powder macerated with $1000 \mathrm{ml}$ of $70 \%$ ethanol), at room temperature. After 48 hours, screening with Whatman number 4 filter paper was carried out. Solvents on the filtrate were identified with a Heidolp rotary evaporator, at a temperature of $40^{\circ} \mathrm{C}, 55 \mathrm{rpm}$. The extract obtained is then called honey bee nest ethanol extract. While the residue continued with maseration using $\mathrm{n}$-hexane as much as $1000 \mathrm{ml}$. After 48 hours, screening was done with Whatman no. 4 filter paper. Solvents were evaporated with a Heidolp rotary evaporator at $40^{\circ} \mathrm{C}, 55 \mathrm{rpm}$. The extract obtained referred to as honey bee nest $\mathrm{n}$-hexane extract.

\section{Bioactive Content Analysis \\ Phytochemical analysis}

Content analysis of phytochemical groups using the method of Harborne (2008) and UV-Vis Spectrophotometer. The crude honey bee nest extract was tested using Wagner solution, Dragendorff solution and Meyer solution. The components analyzed include the content of Alkaloids, Flavonoids, Saponins, Tannins, Streorids and Triterpenoids.

\section{Bioactive analysis of the HPLC method}

Flavonoid analysis of Honey Bee nest was conducted using HPLC. A sample of $2 \mathrm{~g}$ honey bee nest plus $14 \mathrm{~mL}$ acetonotril $70 \%$, then allowed to stand for 24 hours. Samples were filtered using filter paper (Whatmann No.41) and PVDF filter (Milipore). Measurement of phenol levels were performed using HPLC.

\section{RESULTS AND DISCUSSION \\ Extraction}

Extraction is the initial stage to isolate potentially drug-active compounds from plant or animal simplicia. The most important factor, influencing the extraction results, namely solvent, time, and temperature in extraction (Yang, Wang, Ke, Jiang \& Ying, 2007). Apis dorsata Binghami honey bee nest, obtained from the Minahasa forest, was freshly prepared for extraction (Figure 1). Apis dorsata Binghami honey bee nest extraction was carried out using $70 \%$ ethanol solvent, and $n$-hexane. The honey bee nest is freshly blended, into powder, then as much as $250 \mathrm{~g}$, the powder is macerated with $800 \mathrm{~mL} 70 \%$ ethanol, for 48 hours at room temperature. The solvent contained in the filtrate was evaporated used a rotary evaporator, at a temperature of $40{ }^{\circ} \mathrm{C}$, at $48-50 \mathrm{rpm}$, then called ethanol extract. The residue was again macerated with $800 \mathrm{~mL} \mathrm{n}$-hexane for $2 \times 24$ hours at room temperature. The maceration results are then filtered to obtain the filtrate. The solvent was evaporated with a rotary evaporator at a temperature of $40^{\circ}$ C, $50 \mathrm{rpm}$. The extraction results are then called $\mathrm{n}$ hexane extracts (Table 1). Ethanol extract is brown with a distinctive honey bee nest odor, while $n$ hexane extract is yellow with a distinctive honey bee nest odor (Figure 1).

Table 1. Yields of Apis dorsata Binghami honey bee nest extract

\begin{tabular}{clcccc}
\hline Samples & \multicolumn{1}{c}{ Solvents } & $\begin{array}{c}\text { Samples } \\
\text { Weight }(\mathbf{g})\end{array}$ & Yields (\%) & $\begin{array}{c}\text { Extract Weight } \\
(\mathbf{g})\end{array}$ & Colours \\
\hline A1 & Ethanol $70 \%$ & 200 & 7.75 & 5.32 & Brown \\
& n-heksan & 200 & 8.45 & 6.45 & Yellow \\
A2 & Ethanol 70\% & 200 & 8.53 & 5.45 & Brown \\
& n-heksan & 200 & 8.91 & 6.53 & Yellow \\
\hline
\end{tabular}




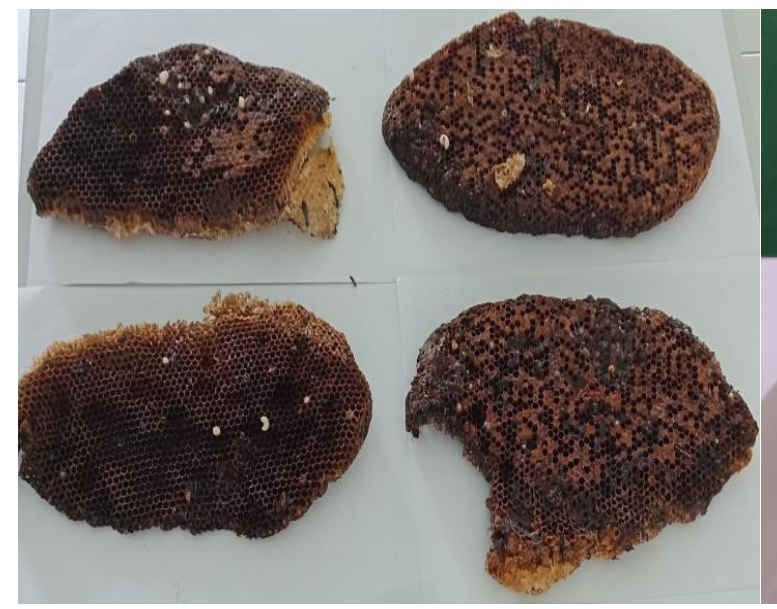

(a)

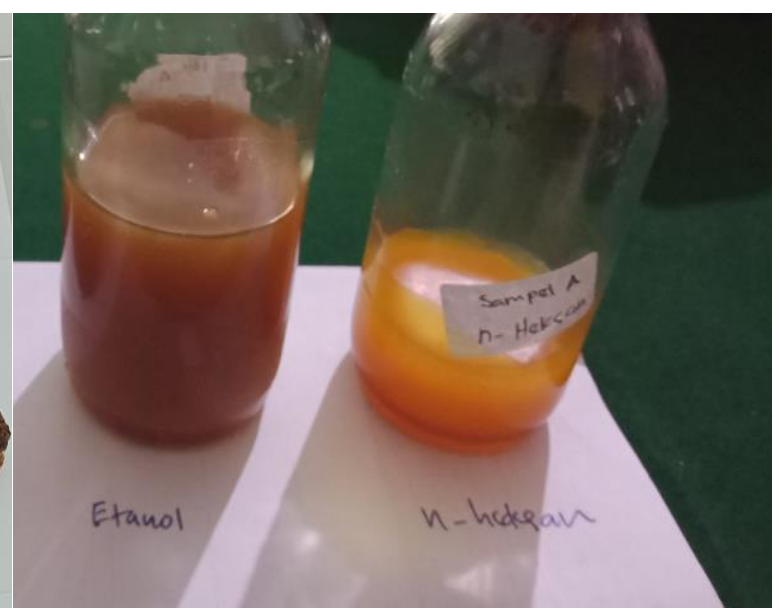

(b)

Figure 2. (a). Apis dorsata Binghami honey bee nest and (b). Apis dorsata Binghami honey bee nest extract

Tabel 2. Phytochemicals analysis results

\begin{tabular}{|c|c|c|c|c|}
\hline \multirow{2}{*}{$\begin{array}{l}\text { Group of } \\
\text { Phytichemistry } \\
\text { Compounds }\end{array}$} & \multicolumn{4}{|c|}{ Results } \\
\hline & A1Et.OH & Alnh & $\mathrm{A} 2 \mathrm{EtOH}$ & A2nh \\
\hline Alkaloid & + & ++ & ++ & + \\
\hline Flavonoid & ++ & + & ++ & + \\
\hline Saponin & ++ & + & ++ & ++ \\
\hline Tanin & + & - & + & + \\
\hline Triterpenoid & + & + & + & + \\
\hline Steroid & ++ & ++ & + & ++ \\
\hline
\end{tabular}

Description :

$(+)$ sign indicates the level of color intensity and deposits formed, after being given the test reaction. $\mathrm{E} \mathrm{OH}$ (ethanol extract), nh (n-hexane extract).

The most widely used method in the study of plant materials as a bioactive source for medicine is the maceration method. In addition to the maceration method, percolation methods, socletation and steam distillation are also often used. Nevertheless, percolation methods are only good for soluble organic compounds, while steam and steam distillation are only good for heat-resistant compounds (Faraouq, 2003; Lenny, 2006; Mokosuli, 2008). According to Faraoug (2003), the extraction of simplicia for the purpose of herbal medicine is the best use of ethanol solvents. Ethanol can mix with water in various comparisons, and it is easy to evaporate the residue in the extract. Methanol, ethylacetate or hexane solvents are not allowed because of toxic residues produced (BPOM, 2018). According to Trusheva, Bankova \& Trunkova, (2007), extracting propolis with ethanol by comparing several extraction methods namely maceration, EU (ultrasound extraction) and MAE (microwave assisted extraction), it turned out that the maceration method produced a total yield of $55.58 \%$ greater than the EU and MAE methods with each yield was $41 \%$ and $53 \%$. The highest yield percentage was obtained from ethanol extract both on $A 1$ and $A 2$, therefore the two extracts were continued in an antioxidant activity bioassay.

\section{Phytochemical Analysis}

Screning content of phytochemicals is a standard procedure in the exploration of plant and / or animal extracts, for the purpose of testing drug activity. Phytochemical analysis aims to determine secondary metabolites, which are contained in honey bee nest extract. Honey bee nest is formed, among others, from the sap of plants taken by worker bees. In A1 ethanol extract, it was identified that all classes of secondary metabolites were tested. Flavonoids, Saponins and Steroids are found in higher intensity than other secondary metabolites. While $n$-hexane extract obtained alkaloid and steroid content in high intensity. In the ethanol extract A2, obtained the content of alkaloids, flavonoids and saponins with a higher intensity than other phytochemicals tested. $n$ hexane A2 extract showed saponin content and steroids with higher intensity than other phytochemical groups (Table 2). 


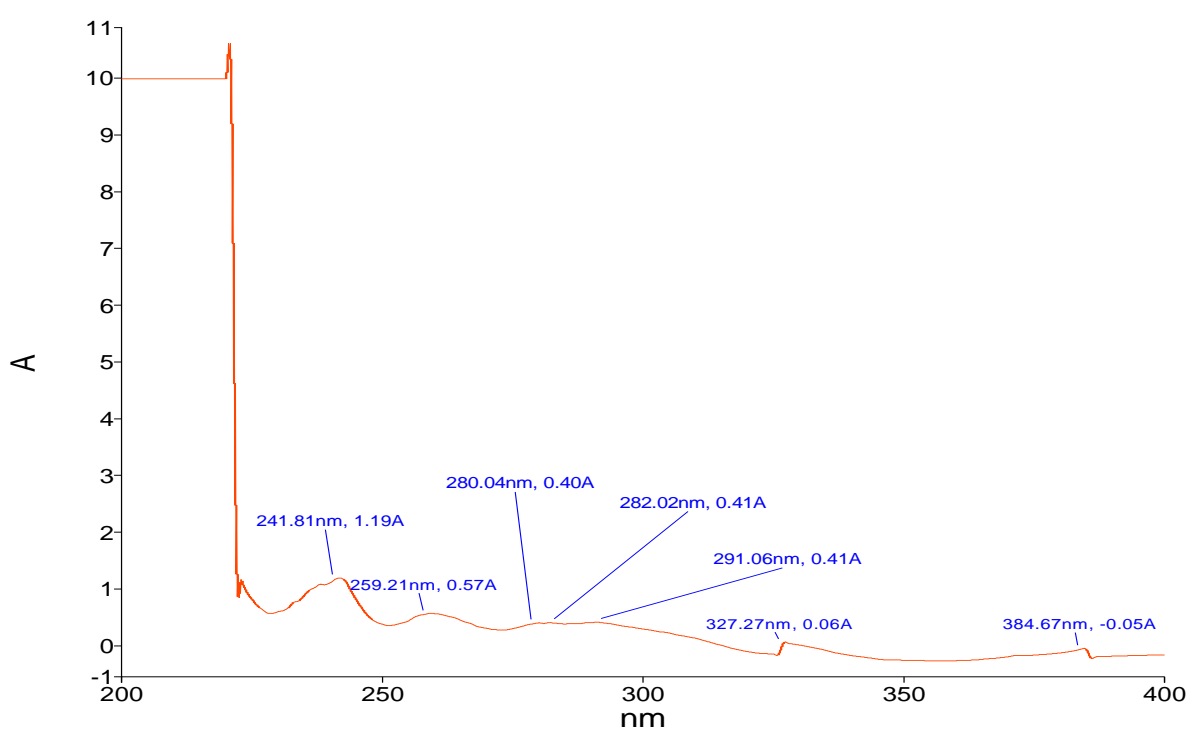

Figure 3. Spectrograph of ethanol extract of Apis dorsata Binghami honey bee nest

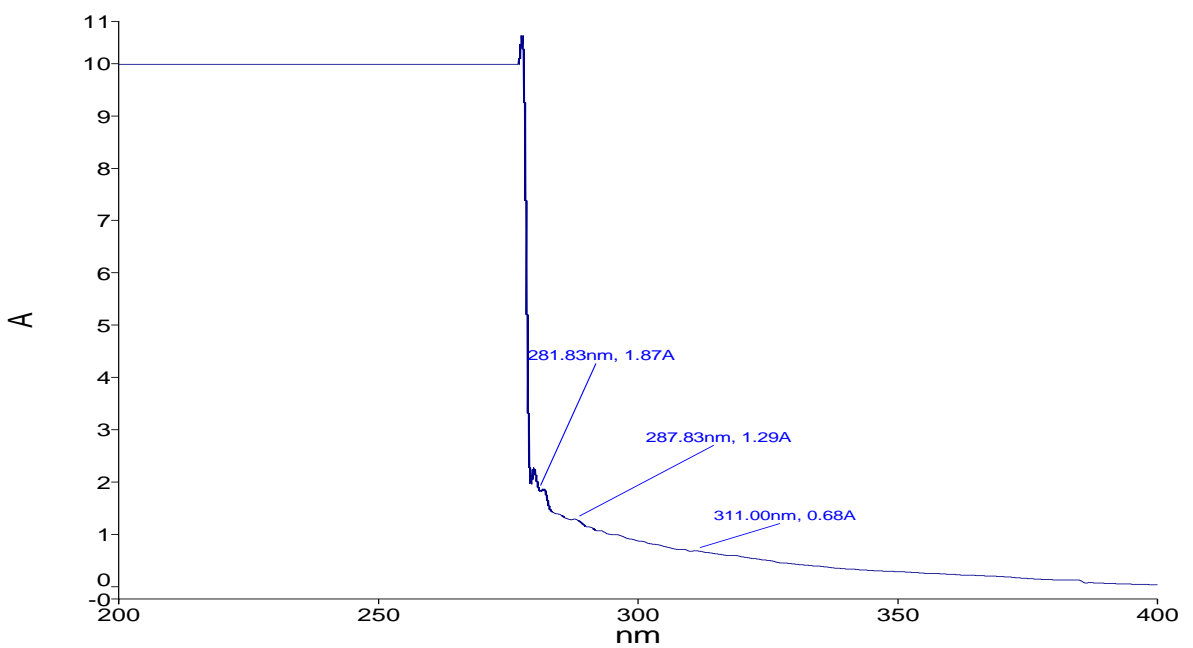

Figure 4. Spectrograph of $n$-heksan extract of Apis dorsata Binghami honey bee nest

In forming a nest, Apis dorsata Binghami requires more than 100 plants, a source of sap (Hadisoesilo 2001; Raffiundin, 2002). The latex is used in forming hexagonal spaces in the honey bee nest, where bee eggs are placed. Previous research, Apis dorsata Binghami nests in Minahasa have specific characteristics (Mokosuli, 2013). Some of the plants that are visited by bees are Syzygium aromaticum, Ficus sp., Ficus minahassae, Durio zebethinus, Lansium minahassae, Elemerelia celebica L, Mangifera indica, Cocos nucifera, Garcinia magostana, Nephelium lappaceum etc.

This reinforces the results of research that Apis dorsata Binghami bee nest contains all phytochemical classes. Extraction is done by maceration and fractionation methods. Ethanol solvents have two different polarity groups, namely polar hydroxyl groups and nonpolar alkyl groups. The existence of this cluster so that compounds with different polarity levels will be extracted in ethanol. n-hexane solvents are non-polar, this causes the secondary non-polar metabolites to be properly withdrawn. Profile of the UV Vis spectrophotometer, both extracts are shown in Figure 3 and Figure 4.

\section{Flavonoid analysis with HPLC}

Analysis of the content of flavonoid compounds was carried out using High performance liquid chormatography. HPLC can separate compounds from the mixture in the honey bee nest extract. Separation of compounds is known in retention time (Seal, 2016). Retention time is the time needed for the compound to move, when it is first injected into the chromatography, to the maximum peak measured (Seal, 2016). Unknown compounds can be observed well using UV light at wavelengths between 200-220 nm (close to the final absorbance), this is due to the fact that organic compounds have absorbance at the spectrum distance (De Oliveira, Nakashima, De Souza \& Frehse, 2001; Rosli et al., 2016). Based on retention, there are 35 types of active compounds in Al honey bee nest extract. Three compounds were found with a percentage above $10 \%$. First, the active compound content was 
$23.63 \%$ with a retention time of 2.773 minutes. Second, the content of the active compound was $14.28 \%$ with a retention time of 3.793 minutes, and the third content of the compound was $11.88 \%$ with a retention time of 2.003 minutes. Quercetin standard shows retention time of 11.854 (Figure 3). Quercetin was identified in Al extract with a higher content compared to extract A2. The lower the sample concentration, the higher the retention time value. This causes the compound to be more difficult to separate from other compounds, if the levels in the sample are not enough.

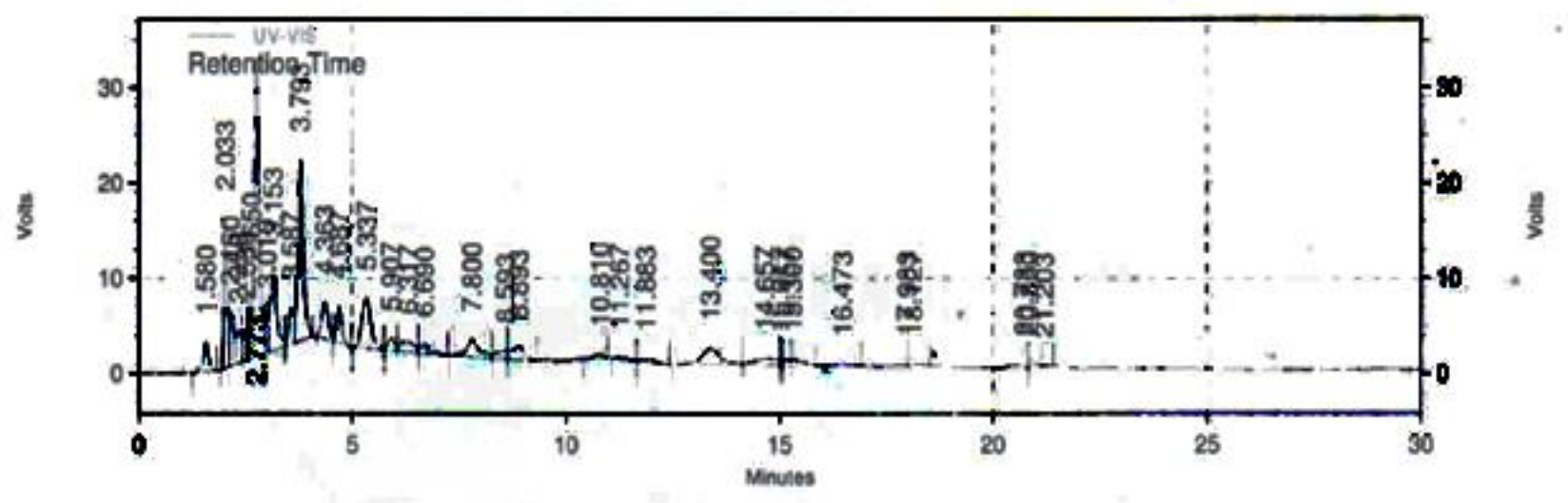

Retention time $\mathrm{Al}(\mathrm{E} \mathrm{FH})$ extract

UV-VIS Results

\begin{tabular}{|c|c|c|c|c|}
\hline Retention Time & Area & Area \% & Heigth & Heigth \% \\
\hline 1.580 & 111790 & 2.24 & 12152 & 2.29 \\
\hline 2.033 & 319951 & 6.42 & 63113 & 11.88 \\
\hline 2.160 & 137408 & 2.76 & 22272 & 4.19 \\
\hline 2.350 & 132494 & 2.66 & 13665 & 2.57 \\
\hline 2.530 & 91519 & 1.48 & 13768 & 2.59 \\
\hline 2.650 & 153338 & 3.08 & 28984 & 5.46 \\
\hline 2.773 & 920666 & 18.47 & 125550 & 23.63 \\
\hline 3.010 & 80798 & 1.62 & 15293 & 2.88 \\
\hline 3.153 & 375551 & 7.53 & 36147 & 6.80 \\
\hline 3.587 & 121473 & 2.44 & 15063 & 2.84 \\
\hline 3.793 & 673915 & 13.52 & 75838 & 14.28 \\
\hline 4.363 & 159673 & 3.20 & 15135 & 2.85 \\
\hline 4.687 & 136630 & 2.74 & 15020 & 2.83 \\
\hline 5.337 & 320943 & 6.44 & 20957 & 3.94 \\
\hline 5.907 & 57300 & 1.15 & 4851 & 0.91 \\
\hline 6.317 & 94395 & 1.89 & 4208 & 0.79 \\
\hline 6.690 & 54456 & 1.09 & 3691 & 0.69 \\
\hline 7.800 & 150424 & 3.02 & 7021 & 1.32 \\
\hline 8.593 & 60223 & 1.21 & 3396 & 0.64 \\
\hline 8.893 & 115809 & 2.32 & 5344 & 1.01 \\
\hline 10.810 & 26331 & 0.53 & 1346 & 0.25 \\
\hline 11.267 & 19501 & 0.39 & 1061 & 0.20 \\
\hline 11.883 & 29545 & 0.59 & 1266 & 0.24 \\
\hline 13.400 & 244190 & 4.90 & 7183 & 1.35 \\
\hline 14.657 & 126413 & 2.54 & 3214 & 0.60 \\
\hline 15.017 & 10649 & 0.21 & 2699 & 0.51 \\
\hline 15.157 & 30248 & 0.61 & 2777 & 0.52 \\
\hline 15.300 & 61692 & 1.24 & 2775 & 0.52 \\
\hline 16.473 & 37909 & 0.76 & 1135 & 0.21 \\
\hline 17.983 & 27225 & 0.55 & 1165 & 0.22 \\
\hline 18.127 & 30895 & 0.62 & 1218 & 0.23 \\
\hline 20.733 & 37102 & 0.74 & 1547 & 0.29 \\
\hline 20.850 & 23213 & 0.47 & 1576 & 0.30 \\
\hline 21.203 & 11130 & 0.22 & 820 & 0.15 \\
\hline
\end{tabular}

Figure 5. Results of UV Vis Spectrophotometry analysis of A1 extract after analysis by HPLC 


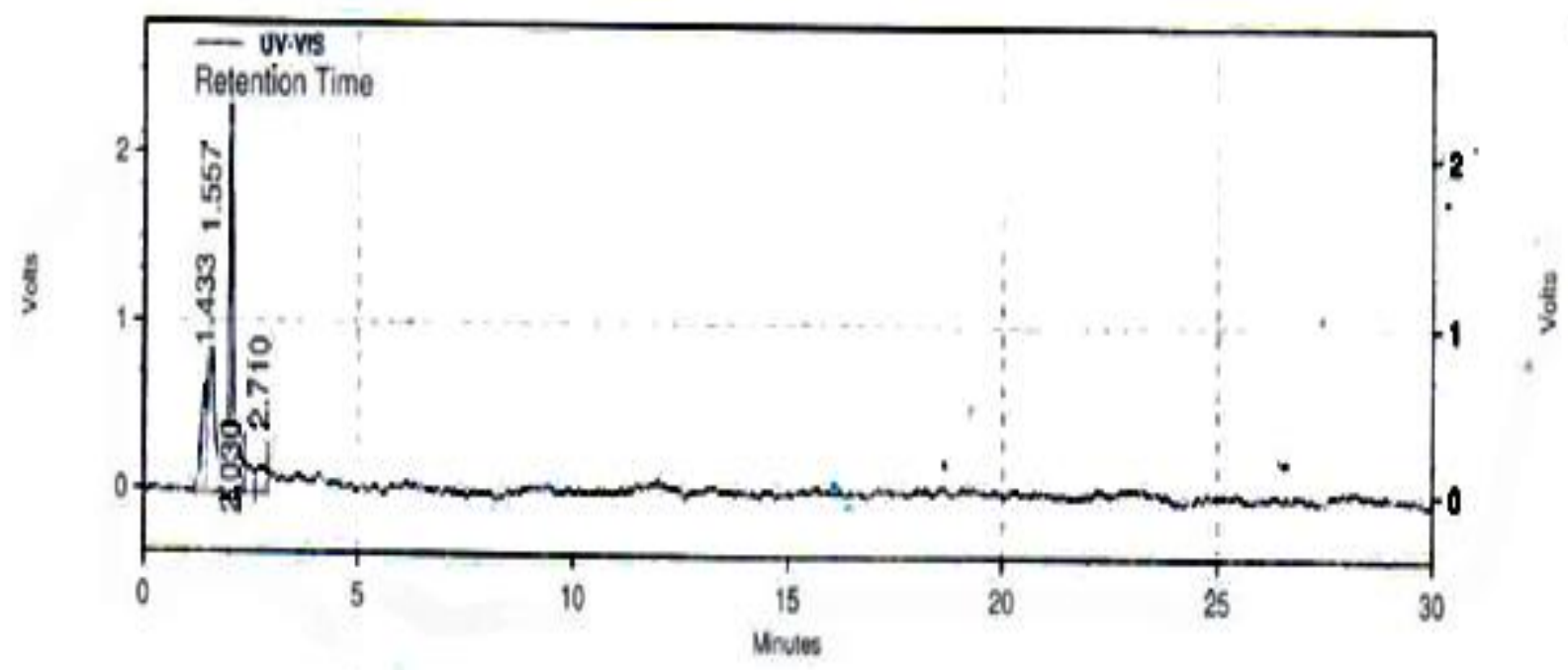

UV-VIS Results

\begin{tabular}{ccccc}
\hline Retention Time & Area & Area \% & Heigth & Heigth \% \\
\hline 1.443 & 20835 & 14.46 & 2570 & 13.99 \\
1.557 & 49079 & 34.06 & 5207 & 28.35 \\
2.030 & 64071 & 44.47 & 9974 & 54.30 \\
2.710 & 10104 & 7.01 & 619 & 3.37 \\
\hline Total & 144089 & 100.00 & 18370 & 100.00 \\
\hline
\end{tabular}

Retention time A2 (n-hexane) extract

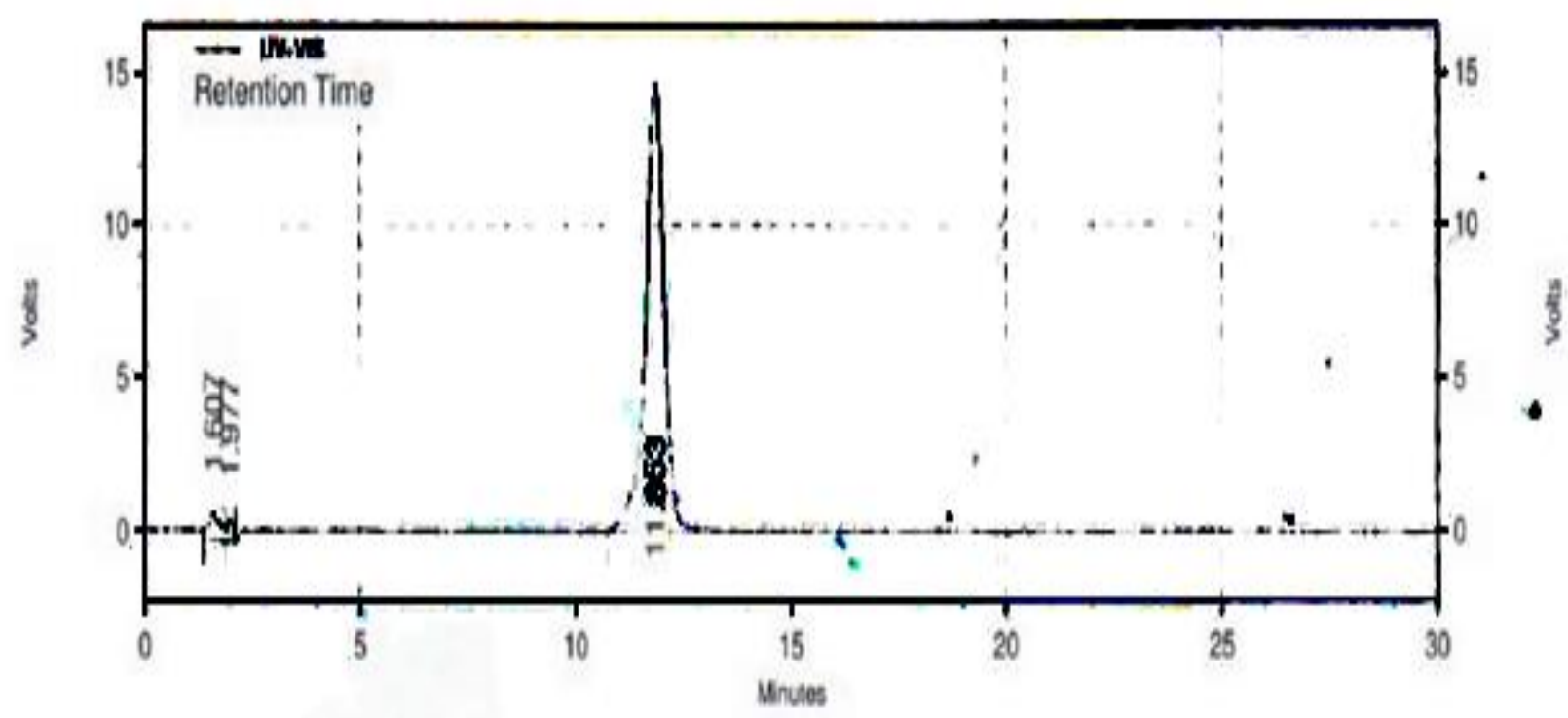

UV-VIS Results

\begin{tabular}{ccccc}
\hline $\begin{array}{c}\text { Retention } \\
\text { Time }\end{array}$ & Area & Area \% & Heigth & Heigth \% \\
\hline 1.607 & 67545 & 3.67 & 3419 & 5.25 \\
1.997 & 27648 & 1.50 & 2902 & 4.45 \\
11.853 & 1743535 & 94.82 & 58835 & 90.30 \\
\hline
\end{tabular}

Figure 6. Quercetin standard retention time and results of UV Vis Spectrophotometer analysis 


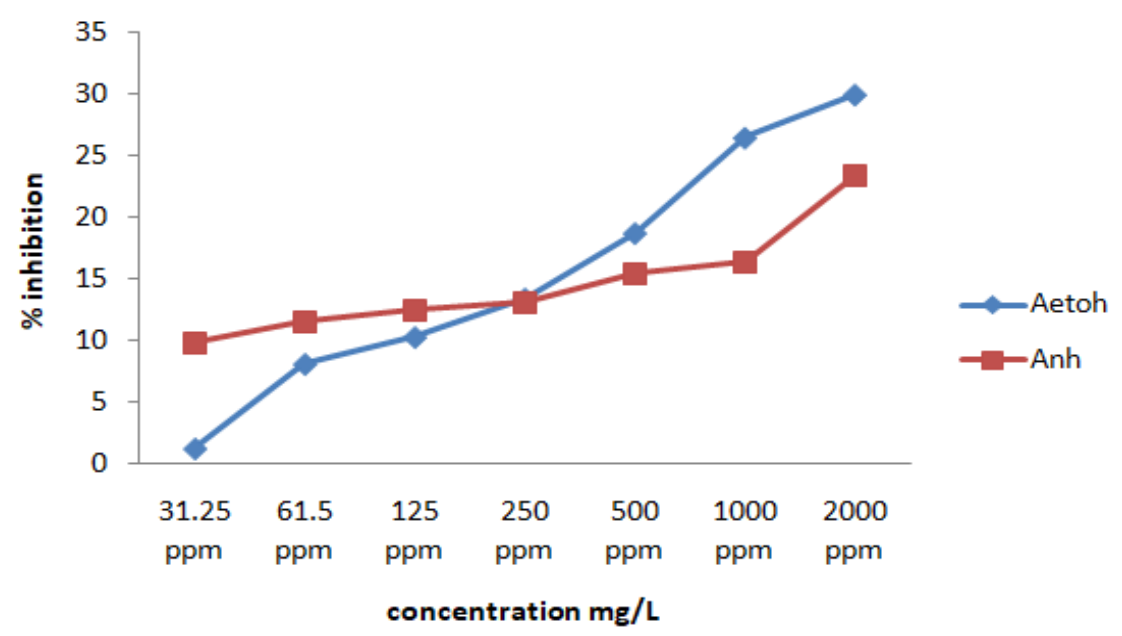

Figure 7. Extract inhibition activity at various test concentrations of DPPH free radicals

\section{Test of antioxidant activity}

Antioxidant test method DPPH 1,1-diphenyl-2picrylhydrazyl is widely used to determine the antioxidant potential of plant extracts. Antioxidant activity in honey bee nest extract, reacts with DPPH free radicals by donating hydrogen atoms, causes changes in DPPH color from purple to yellow. Color intensity was measured by spectrophotometer at a wavelength of $517 \mathrm{~nm}$ (Mokosuli 2008). The principle of this antioxidant activity test method is to quantitatively measure antioxidant activity by measuring DPPH radical capture by a compound that has antioxidant activity using UV-Vis spectrophotometry, so that the value of activity of free radical reduction is expressed as $\mathrm{IC}_{50}$ value (Inhibitory Concentration) (Kikuzaki \& Nakatani, 1993). Antioxidant activity was obtained from the percentage of inhibition of Apis dorsata Binghami honey bee nest extract, against DPPH radical. The percentage of inhibition was obtained from differences in absorption between DPPH absorbance and absorbance of the sample measured by UV-Vis spectrophotometer. The amount of antioxidant activity is indicated by the $\mathrm{IC}_{50}$ value, which is the concentration of the sample solution needed to inhibit 50\% DPPH free radicals. Based on the distribution of test concentrations, ethanol extract (Aetoh) had the best free radical inhibitory percent compared to $n$-hexane (Anh) extract (Figure 7).

Table 4. $I_{50}$ value of the antioxidant activity of Apis dorsata Binghami honey bee nest extract

\begin{tabular}{ll}
\hline Samples & $\mathrm{IC}_{50}(\mathrm{ppm})$ \\
\hline Vit C (control) & 6.73 \\
Ethanol extract (AE†OH) & 6.690 \\
n-heksan extract (Anh) & 6.766 \\
\hline
\end{tabular}

Compared to the positive control of vitamin $\mathrm{C}$ with $I_{50}(6.73 \mathrm{mg} / \mathrm{L})$, ethanol extract has a better
$\mathrm{IC}_{50}$ value of $6.69 \mathrm{mg} / \mathrm{L}$. Whereas $\mathrm{n}$-hexane extract has a lower $I C_{50}$ value of $6.76 \mathrm{mg} / \mathrm{l}$ (Table 1). Based on the $\mathrm{IC}_{50}$ obtained, honey bee nest extract is very potential to be used as a source of bioactive antioxidants. The honey bee nest extract used is still a crude extract while vitamin $C$ used as a control is a pure compound. A compound is said to be a very strong antioxidant if the $\mathrm{IC}_{50}$ value is $<50 \mathrm{ppm}$, strong for $\mathrm{IC}_{50}$ is $50-100 \mathrm{ppm}$, while if $\mathrm{IC}_{50}$ is 100 $150 \mathrm{ppm}$, it is weak if $I_{50}$ is $150-200 \mathrm{ppm}$, and very weak if the $I C_{50}$ value is $>200 \mathrm{ppm}$ (Mardawati, Filianty \& Marta, (2008)

DPPH free radical reduction activity of ethanol extract was stronger than $n$-hexane extract, supported by the content of active compounds contained in the extract. Based on the analysis of the content of phytochemical groups, ethanol extract has higher intensity of flavonoid, saponin and tannin content compared to $\mathrm{n}$-hexane extract. The group of phenolic compounds, has been widely reported to have strong antioxidant activity. The $\mathrm{n}$-hexane extract contains more compounds with lipid basic precursors such as triterpenoids and steroids.

Flavonoids act as free radical scavenger by giving hydrogen atoms to free radicals (Sanomiya, Fonseca \& Silva, 2005). Free radical scavenging activity of flavonoids depends on the molecular structure and the form of substitution of hydroxyl groups such as the ability of phenolic hydrogen and the possibility of stabilization by phenoxyl radicals through hydrogen bonds or electron delocalisation. Structural activity activities (SAR) of important flavonoids are known, namely the number and location of $\mathrm{OH}$ phenolic groups that play a role in neutralizing free radicals (Amic, Davidovic, Beslo, \& Trinajstic, 2003). Based on the analysis by HPLC there were more than 20 types of flavonoids contained in the ethanol extract of Apis dorsata Binghami honey bee nest while in $n$ hexane extract only found 4 flavonoid compounds. Flavonoid compounds such as quercetin, kaempferol, 
myricetin, apigenin, luteolin, vitexin and isovitexin are found in cereals, vegetables, fruits and their processed products with various ingredients and most have antioxidant properties. This has reinforced the notion that flavonoids have certain biological effects, related to their antioxidative properties.

A mixture of several polyphenol compounds is able to function synergistically with other components as antioxidants and damping free radicals and prevention of various diseases (Meskin, Bidlack, Davies \& Omaye, 2002). However, the antioxidant activity testing method is very influential in producing IC50 values (Shalaby and Sanaa, 2012). The difference in the value of anti-oxidant activity is caused by the extraction method, the testing method and the operating conditions used when the extraction process also differs (solvent volume, leaf powder size, extraction time+, temperature, and pressure). Antioxidant activity is influenced by extraction methods and operating conditions used during extraction (Chuv et al. 2012).

\section{CONCLUSIONS}

Apis dorsata Binghami honey bee nest extract from Minahasa based on phytochemical analysis was identified to contain alkaloids, flavonoids, saponins, tannins, steroids and triterpenoids. Identified flavonoids are the highest phytochemical content. Based on the results of HPLC and UV Vis spectrophotometer analysis, there were 20 flavonoid derivatives found in honey bee nest samples in Minahasa. Ethanol extract and $n$-hexane extract showed high free radical reduction activity compared to vitamin $\mathrm{C}$ control. However, ethanol extract was found to has the highest DPPH free radical reduction activity.

\section{Recommendations}

In the future, it is necessary to study anticancer and antihyperlipidema activities of Apis dorsata Binghami nest extract.

\section{AKNOWLEDGMENTS}

Gratitude to the directorate of research and community service, Ministry of research, technology and higher education, Republic of Indonesia, which has financed the implementation of this research, in 2018.

\section{REFERENCES}

Amic, D., Davidovic-Amic, D., Beslo, D., Trinajstic, N. (2003). Structure-Radical Scavenging Activity Relationships of Flavonoids. Croatica Chemica Acta. 76(1), 55-61.

Bankova, V. 2005. Recent trends and important developments in propolis research. eCAM;2(1), 29-32. doi:10.1093/ecam/neh059

Barrientos, L., Herrera, C. L., Montenegro, G., Ortega, X., Veloz, J., Alvear, M., Cuevas, A.,
Saavedra, N., \& Salazar, L.A. (2013). Chemical and botanical characterization of Chilean propolis and biological activity on cariogenic bacteria Streptococcus mutans and Streptococcus sobrinus. Brazillian. Journal of. Microbiology 44(2), 577-585. http://dx.doi.org/ 10.1590/S1517. 83822013000200038.

BPOM R. I. ( Badan Pengawasan Obat dan Makanan Republik Indonesia). (2018). Peraturan badan pengawas obat dan makanan republik indonesia tentang kriteria dan tata laksana registrasi obat tradisional. http://jdih.pom.go.id/rancanganpublikshowpd f.php?u.

Choi, S. J., Shimomura, K., Kumazawa, S., \& Ahn, M. R. (2013). Antioxidant Properties and Phenolic Composition of Propolis from Diverse Geographic Regions in Korea. Food Science and Technology Research, 19 (2), 211-222. https://doi.org/10.3136/fstr.19.211

Chuv, C. P., Lin H. P., Ciaccio, M. F., Kokontis J. M., Hause R. J., Hiipakka R. A., Liao, S., \& Jones R. B. (2012). Caffeic Acid Phenethyl Ester Suppresses the Proliferation of Human Prostate Cancer Cells through Inhibition of p70S6K and Akt Signaling Networks. Cancer Prevention Research,; 5 (5): 788 DOI: 10.1158/19406207.CAPR-12-0004-T.

Coneac, G., Gatifanu, E., Hadaruga, D. I., Hadaruga, N. G., Pinzaru, I. A., \& Bandur, G. (2008). Flavonoid Content of Propolis from the West Side of Romania and Correlation with the Antioxidant Activity. Chemical Bulletin Politechnic.; 53(67):56-60.

De Oliveira, B. H., Nakashima, T., De Souza Filho, J. D., \& Frehse, F. L. (2001). HPLC Analysis of Flavonoids in Eupatorium littorale. Journal of the Brazilian Chemical Society, 12(2), 243$246 . \quad$ https://doi.org/10.1590/S010350532001000200019

Daleprane, J. B., \& Abdall, D. S. (2013). Emerging Roles of Propolis: Antioxidant, Cardioprotective, and Antiangiogenic Actions. Evidence-Based Complementary and Alternative Medicine. Volume 2013, Article ID 175135, 8 pages (1-8) http://dx.doi.org/ $10.1155 / 2013 / 175135$

Farooqui, T., and Farooqui, A. A. (2010). Molecular Mechanism Underlying the Therapeutic Activities of Propolis: A Critical Review. Current Nutrition \& Food Science, pp.7-15, Vol. 6, No.3

Faraouq, (2003). Ekstrak sebagai salah satu pengembangan bentuk obat tradisional. Prosiding Seminar Nasional Tumbuhan Obat Indonesia XXIII, Jakarta. 45-52 
Hadisoesilo, S. (2001). Review: Keanekaragaman Spesies Lebah Madu Asli Indonesia. Biodiversitas 2, 123-128.

Hadisoesilo, S., Raffiudin, R., Susanti, W., Atmowidi, T., Hepburn C, Radloff S. E., Fuchs S., \& Hepburn R. (2007). Morphometric analysis and biogeography of Apis koschevnikovi Enderlein (1906). Apidologie 39 DOI: 10.1051/apido:2008029

Harborne, J. B. (2008). Metode Fitokimia, penuntun dan cara modern menganalisis tumbuhanPeneriemah : Padmawinata K dan Soediro I. Penerbit ITB Bandung

Hattenschwiller, S., \& Vitousek, P. M. (2000). The role of polyphenols in terrestrial ecosystem nutrient cycling. Trends Ecology Evolution. Jun;15(6):238-243.

Inggrid, M., \& Santoso, H. (2014). Ekstraksi Antioksidan Dan Senyawa Aktif Dari Buah Kiwi ( Actinidia deliciosa ). Lembaga Penelitian Dan Pengabdian Kepada Masyarakat, III(3), 43.

Kikuzaki, H., \& Nakatani, N. (1993). Antioxidant effects of some ginger constituents. Journal of Food Science 58:1407-10.

Lenny, S. (2006). Isolasi dan uji bioaktivitas kandungan kimia utama puding merah dengan metode uji brine shrimp. USU Repository, Medan.

Meskin, M. S., Bidlack W. R., Davies, A. J., \& Omaye S. T. (2002). Phytochemicals in Nutrition and Health. CRC Press, London, New York.

Mokosuli, Y. S. (2008). Aktivitas antioksidasi dan antikanker ekstrak kulit batang Langsat (Lansium domesticum L.). (Tesis). Sekolah Pascasarjana Institut Pertanian Bogor.

Mokosuli, Y. S. (2013). Karakter Morfologi, Sumber Pakan, Dan Bioaktivitas Farmakologis Racun Lebah Madu Endemik Sulawesi Apis dorsata Binghami DAN Apis nigrocincta Smith (HYMENOPTERA : APIDAE). (Disertasi). Program Pascasarjana Universitas Sam Ratulangi, Manado.

Mokosuli, Y. S. \& Repi, R. A. (2015). The Characteristics Of Bioactive Peptides And Antibacterial activity of honey bee (Apis nigrocincta) smith venom, endemic to sulawesi. Molekul, Vol. 10. No. 2. November: $135-144$

Mardawati, F., Filianty, \& Marta, H. 2008. Kajian aktivitas antioksidan ekstrak kulit manggis (Garcinia mangostana L) dalam rangka pemanfaatan limbah kulit manggis di Kecamatan Puspahiang Kabupaten Tasikmalaya. Fakultas Teknologi Industri. Universitas Padjadjaran.

Nazzi, F. (2016). The hexagonal shape of the honeycomb cells depends on the construction behavior of bees. Sci Rep. 2016; 6: 28341.
Published online 2016 Jun

20. doi: 10.1038/srep28341.

Otis, G.W. (1991). Revised distribution of three recently recognized species of honey bees in Asia. Honeybee Science 15:167-170.

Pasupuleti, V. R., Sammugam, L., Ramesh, N., \& Gan, S. H. (2017). Honey, Propolis, and Royal Jelly: A Comprehensive Review of Their Biological Actions and Health Benefits. Oxidative Medicine and Cellular Longevity. Volume 2017, Article ID 1259510, 21 pages https://doi.org/10.1155/2017/1259510

Pérez-Pérez, E. M., Suárez, E., Peña-Vera, M. J., González, A. C., \& Vit, P. (2013). Antioxidant activity and microorganisms in nest products of Tetragonisca angustula Latreille, 1811 from Mérida, Venezuela. pp. 1-8. In Vit P \& Roubik DW, eds. Stingless bees process honey and pollen in cerumen pots. Facultad de Farmacia y Bioanálisis, Universidad de Los Andes; Mérida, Venezuela.

Raffiudin, R. (2002). Honey bee behavioural evolution and itpr gene structure studies. [PhD Thesis]. James Cook University http::eprints.jcu.edu.au/1249

Redha, A. (2010). Flavonoid: Struktur, Sifat Antioksidatif dan Peranannya Dalam Sistem Biologis. Jurnal Berlin, 9(2), 196-202. https://doi.org/10.1186/2110-5820-1-7

Ra'ed, J. A., Ibrahim, K. N., Rula, M. D., \& Mosa, A. (2008). Honey Bee Hive Modification for Propolis Collection. Jordan Journal of Agricultural Sciences, Vol 4(2)

Repi, R. A., Mokosuli, Y.S., Ngangi, J., \& Sumampouw, H. M. (2013). Hepatoprotective Activity Combination Between Morinda Citrifolia Linn (Mengkudu) Extract And Virgin Coconut Oil (VCO). Journal of Biology, Agriculture and Healthcare. Vol.3, No.13, pp 160-166.

Rosli, N. L., Roslan, H., Oma, E. A., Mokhtar, N., Hapit, N. H. A., \& Asem N. (2016). Phytochemical analysis and antioxidant activities of Trigona Apicalis propolis extract. AIP Conference Proceedings 1791, 020018 2016; doi: 10.1063/1.4968873. https://aip.scitation.org/toc/apc/1791/1 ?expa nded $=1791$

Sannomiya, V. B., Fonseca, M. A. D., \& Silva L. (2005). Flavonoids and antiulcerogenic activity from Byrsonima crassa leaves extracts. Journal of Ethnopharmacology, vol.97, no. 1,pp. 1-6,

Sawaya, A. C. H. F., Calado, J. C. P., Santos, L. C. D. S., Marcucci, M. C., Akatsu, I. P., \& Soares, A. E. E. S., Abdelnur, P. V., Cunha I. B. D. S., and Eberlin M. N. (2009). Composition and antioxidant activity of propolis from three species of Scaptotrigona stingless bees. Journal of ApiProduct and ApiMedical Science 1 (2): 
37 - 42 (2009). DOI 10.3896/IBRA.4.01.2.03

Saavedra, N., Barrientos, L., Herrera, C. L., Alvear, M., Montenegro G., \& Salazar L. A. (2011). Effect of Chilean propolis on cariogenic bacteria Lactobacillus fermentum. Ciencia Investigacion Agraria. [online]. vol.38, n.1, pp.117-125. ISSN 0718$1620 . \quad$ http://dx.doi.org/10.4067/S071816202011000100011.

Shalaby, E. A., \& Sanaa, M. M. S., (2012). Comparison of DPPH and ABTS assays for determining antioxidant potential of water and methanol extracts of Spirulina platensis. Indian Journal of Geo-Marine Sciences 42(5):556564.

Seal, T. (2016). Quantitative HPLC analysis of phenolic acids, flavonoids and ascorbic acid in four different solvent extracts of two wild edible leaves, Sonchus arvensis and Oenanthe linearis of North-Eastern region in India. Journal of Applied Pharmaceutical Science, 6(2), 157-166. https://doi.org/10.7324/ JAPS.2016.60225.

Suseno, D., (2009). Aktivitas Antibakteri Propolis Trigona spp. Pada Dua Konsentrasi Berbeda
Terhadap Cairan Rumen Sapi. https://repository.ipb.ac.id/bitstream/handle/1 23456789/12572/G09dsu 1. pdfsequence $=2$.

Trusheva, B., Bankova, V., \& Trunkova, D., (2007). Different extraction methods of biologically active components from propolis: A preliminary study. Chemistry Central Journal, 1:13 doi:10.1186/1752-153X-1-13.

Veloz, J. J., Saavedra, N., Alvear, M., Zambrano T., Barrientos, L., \& Salazar, L. A. (2016). Polyphenol-Rich Extract from Propolis Reduces the Expression and Activity of Streptococcus mutans Glucosyltransferases at Subinhibitory Concentrations. BioMed Research International Volume 2016, Article ID 4302706, 7 pages http://dx.doi.org/10.1155/2016/4302706

Waji, R. A., \& Sugrani, A. (2009). Makalah Kimia Organik Bahan Alam Flavonoid (Quertecin). Fakultas Matematika Dan Ilmu Pengetahuan Alam Universitas Hasanuddin, 23.

Yang, D., Wang Q., Ke, L., Jiang J., \& Ying T. (2007). antioxidant activities of various extracts of lotus (Nelumbo nucifera Gaertn) rhizome. Asia Pacific Journal of Clinical Nutrition. 16 (Suppl 1): 158-163. 